\title{
Sensory profile of Italian salami with coriander (Coriandrum sativum L.) essential oil
}

\author{
Perfil sensorial de salame tipo italiano com óleo essencial de coentro (Coriandrum sativum L.)
}

\author{
Cristiane MARANGONI ${ }^{1 \star}$, Neusa Fernandes de MOURA ${ }^{1}$
}

\begin{abstract}
The descriptive terminology and sensory prolife of four samples of Italian salami were determined using a methodology based on the Quantitative Descriptive Analysis (QDA). A sensory panel consensually defined sensory descriptors, their respective reference materials, and the descriptive evaluation ballot. Twelve individuals were selected as judges and properly trained. They used the following criteria: discriminating power, reproducibility, and individual consensus. Twelve descriptors were determined showing similarities and differences among the Italian salami samples. Each descriptor was evaluated using a $10 \mathrm{~cm}$ non-structured scale. The data were analyzed by ANOVA, Tukey test, and the Principal Component Analysis (PCA). The salami with coriander essential oil (T3) had lower rancid taste and rancid odor, whereas the control (T1) showed high values of these sensory attributes. Regarding brightness, T4 showed the best result. For the other attributes, T1, T2, T3, and T4 were similar.
\end{abstract}

Keywords: salami; sensory analysis; quantitative descriptive analysis; principal component analysis.

\section{Resumo}

Foi determinado o perfil sensorial de quatro amostras de salame tipo italiano, com adição de óleo essencial de coentro, pela metodologia fundamentada na Análise Descritiva Quantitativa (ADQ). A equipe sensorial definiu os termos descritores, os materiais de referência para o treinamento das qualidades e quantificações de cada um dos termos e a ficha de avaliação das amostras, de forma consensual. Doze provadores foram selecionados e rigorosamente treinados para compor a equipe definitiva, utilizando-se como critérios o poder discriminativo, reprodutibilidade e consenso dos provadores entre si. Foram gerados 12 termos descritores pelo método de rede. A intensidade de cada descritor foi avaliada em cada amostra por escala não estruturada de $10 \mathrm{~cm}$. Os dados foram analisados por ANOVA, teste de Tukey e análise de componentes principais. O salame com óleo essencial de coentro (T3) apresentou menor sabor ranço e odor ranço, enquanto o controle (T1), apresentou valores altos para estes atributos sensoriais. Para brilho, T4 apresentou o melhor resultado. Para os demais atributos, T1, T2, T3 e T4 ficaram semelhantes.

Palavras-chave: salame; análise sensorial; análise descritiva quantitativa; análise de componentes principais.

\section{Introduction}

According to the Technical Regulation of Identity and Quality, salami is defined as a "meat product obtained from industrialized swine (pork) and beef with the addition of bacon, and other ingredients, and it is packed in a natural or artificial package, dried, fermented, and left to mature; sometimes it is smoked" (BRAZIL, 2000).

For Kroon and Williamson (1999) and Melo and Guerra (2002), in the last 20 years there has been more studies in the search for certain types of foods that carry biologically active substances that bring health benefits or desirable physiological effects (PARK; KOO; CARVALHO, 1997), and a healthier lifestyle. In this context, the antioxidants can delay the oxidative damage in the tissues by increasing their natural defenses (GONÇALVES, 2009).

The toxicological aspects of antioxidants have been one of the biggest areas of controversy in discussions about the safety of food additives. The interest in natural antioxidants began in the 80 's before the proof of evil effects caused by high doses of BHT (butylhidroxitolueno), BHA (butylhidroxianisol), and TBHQ (t-butilhidroquinona). As a result, considerable emphasis has been given to the identification and purification of new compounds from natural sources with antioxidant activity, which can act alone or synergistically with other additives, as an alternative to prevent oxidative deterioration of food and limit the use of synthetic antioxidants (MELO; GUERRA, 2002).

Among the methods of sensory analysis, the Quantitative Descriptive Analysis (QDA) is the one that describes and quantifies the sensory attributes (GILLETTE, 1984) by determining the sensory properties of products and measuring the intensity in which they were perceived by consumers, which allows the quantification of sensory characteristics precisely in mathematical terms (MOSKOWITZ, 1988).

It seems that most of the sensorial analyses studies do not address meat products that or the addition of natural antioxidants.

Recebido para publicação em 25/1/2009

Aceito para publicação em 8/7/2009 (004035)

${ }^{1}$ Ciências Ambientais, Universidade Comunitária Regional de Chapecó - UNOCHAPECÓ, Av. Senador Attílio Fontana, 591-E, Efapi, CP 1141, CEP 89809-000,

Chapecó - SC, Brasil, E-mail: eng.cristiane@gmail.com

${ }^{*}$ A quem a correspondência deve ser enviada 
Hence, this work aimed to establish the sensory profile of four treatments of Italian salami with different concentrations of coriander essential oil.

\section{Materials and methods}

\subsection{Preparation of samples}

Samples of four treatments of Italian salami, T1 (Control), T2 $(0.01 \%$ of coriander), T3 (0.01\% of BHT), and T4 $(0,005 \%$ of coriander $+0,005 \%$ of BHT ) were subjected to sensory analysis in triplicate after 90 days of their preparation (30 days of maturation and 60 days of shelf-life) (MOSKOWITZ, 1988).

\subsection{Presentation of samples}

At least $30 \mathrm{~g}$ of the samples were presented to the panelists at room temperature, coded with three digit random numbers, and randomized order of presentation (MOSKOWITZ, 1988).

\subsection{Conditions of test}

The QDA was performed in individual booths in a laboratory of sensory analysis under white light.

\subsection{Pre-selection of the team tasters}

Initially 20 tasters, consumers of salami who showed interest and availability were pre-selected. The tasters did not know the technique of $A D Q$, but they had previous experience with sensory analysis facilitating the training (MOSKOWITZ, 1988).

The tasters were previously selected using the triangular test (STONE; SIDEL, 1992). The criterion used for the selection of the tasters was the significance level of 5\% according to the specific table test.

\subsection{Attributes evaluation}

The survey was conducted evaluating the attributes of the method of network (Figure 1). Six sessions were held, and for each test, two samples of salami were presented. The panelists were required to show their similarities and differences cleansing their palate with water (at room temperature) and bread.

Name: Date:
Please evaluate the two samples on appearance, aroma, flavor and
texture, indicating that they are similar and they are different.
Sample: and
Appearance
Texture
Flavor
Aroma

Figure 1. Data for implementing the method for network development of descriptive terminology. Source: Damásio and Silva (1996).

\subsection{Preparation of individual scores}

After determining the descriptive terms of the salami samples and discussing the experiment over with the leader and the panelists, lists of sensorial attributes were drawn and the scores of the attribute intensity scale were defined. In the present study, unstructured $10 \mathrm{~cm}$-scales were used.

\subsection{Analysis of the treatments of salami}

Four Italian salami treatments were performed followed by sensory analysis with three replicates resulting in four sessions. A total of 29 sessions were held, three for the selecting panelists, six for evaluating the attributes two for discussing the terms and checking the records, two for the preliminary tests, and 12 for evaluating the samples (three for each treatment).

\subsection{Statistical analysis}

Statistical analysis was performed using the statistical SAS software (STATISTICAL..., 2001). The data were submitted to analysis of variance (ANOVA), partitioned into components attributable to different sources of variation (sample, taster, interaction sample - taster), to a test for comparison of means (Tukey's test), and to the principal component analysis (ACP) according to Stone et al. (1974) and Stone and Sidel (1992).

\section{Results and discussion}

\subsection{Pre-selection of the panelists' team}

Among the 20 panelists who participated in the triangle test, 12 obtained significance values of $5 \%$ and were thus recruited. All of them had shown interest and time availability to participate in the analysis of Italian salami.

\subsection{Determination of attributes and panelists' training}

With the help of the leader, the panelists reached a consensus on the attributes and their meanings, as shown in Chart 1.

After defining the descriptive terms, the panelists were prepared for the evaluation of the samples by means of descriptive analysis, which is shown in Figure 2.

\subsection{Analysis of the treatments of salami after 90 days of storage}

The sensory profile of each one of the four treatments performed at 90 days of maturation of the Italian salami is shown graphically in Figure 3. This figure shows the average response given by the panelists to each descriptive word, which is marked on the corresponding axis, and the center of the graph represents the zero point of the scale used in the evaluation, whereas the intensity increases from the center to the periphery.

As a result of the assessment that describes the sensory profile of the four treatments, could be observed that the addition of coriander essential oil interferes with the color 
Chart 1. List of consensual descriptive terms obtained by the evaluation of tasters.

\begin{tabular}{|c|c|}
\hline Attributes & Definitions \\
\hline \multicolumn{2}{|l|}{ Appearance } \\
\hline Intensity of red & Refers to the intensity of red \\
\hline Brightness & Refers to the brightness of the surface of salami \\
\hline \multicolumn{2}{|l|}{ Aroma } \\
\hline Coriander & Refers to the scent of coriander \\
\hline Acid & $\begin{array}{l}\text { Refers to the aroma acid (result of lactic fer- } \\
\text { mentation) }\end{array}$ \\
\hline Smoked & $\begin{array}{l}\text { Refers to the smell of smoke (as a result of the } \\
\text { smoking process) }\end{array}$ \\
\hline Rancid & Refers to the rancid aroma \\
\hline \multicolumn{2}{|l|}{ Texture } \\
\hline Stiffness & Refers to the rigidity of the samples \\
\hline Elasticity & $\begin{array}{l}\text { Refers to the speed with which the deformed } \\
\text { material returns to its original state after the } \\
\text { removal of the force that deformed it. }\end{array}$ \\
\hline \multicolumn{2}{|l|}{ Flavor } \\
\hline Coriander & Refers to the taste of coriander \\
\hline Acid & Refers to acid taste \\
\hline Savory & Refers to salty taste \\
\hline Rancid & Refers to rancid taste \\
\hline
\end{tabular}

of the product by intensifying its red color. Table 1 shows the average values assigned by the panelists to each descriptive term. To attribute the intensity of the color red, a better sensory quantification, a better sensory quantification of 5.01 was determined for Treatment 2 . which differed significantly from Treatment 1, which showed value of 3.68. Treatments 3 and 4 showed similar scores for this attribute.

For the attributes of stale aroma and rancid taste, the analysis indicated that Treatment 2 (coriander with essential oil) received the lowest scores for these attributes by the tasters, thereby indicating that the coriander essential oil has the ability to delay the lipid oxidation and the development of stale flavor and smell. In contrast, the control, which received no addition of natural or synthetic antioxidants, received the highest scores for rancid aroma and taste showing worse state of preservation.

Treatment 4 (with coriander and BHT) presented the best score for the attribute brightness, 5.9, whereas Treatment 1 (control) had the lowest score, 3.37. This result indicates that the mixture of coriander essential oil with BHT presented better results for the attribute of brightness that those presented by the use of antioxidants alone.

For the attributes rigidity and elasticity, there were no significant differences between the scores given by tasters with 90 days of storage (Table 1).

The terms acid flavor and acid aroma described did not differ significantly between the four treatments evaluated.
Sensory characterization of Italian salami type using descriptive analysis by free profile.

Name: $\quad$ Date:

Sample:

Check on the intensity scale for the attribute indicated.

Aspect of salami

Intensity of red

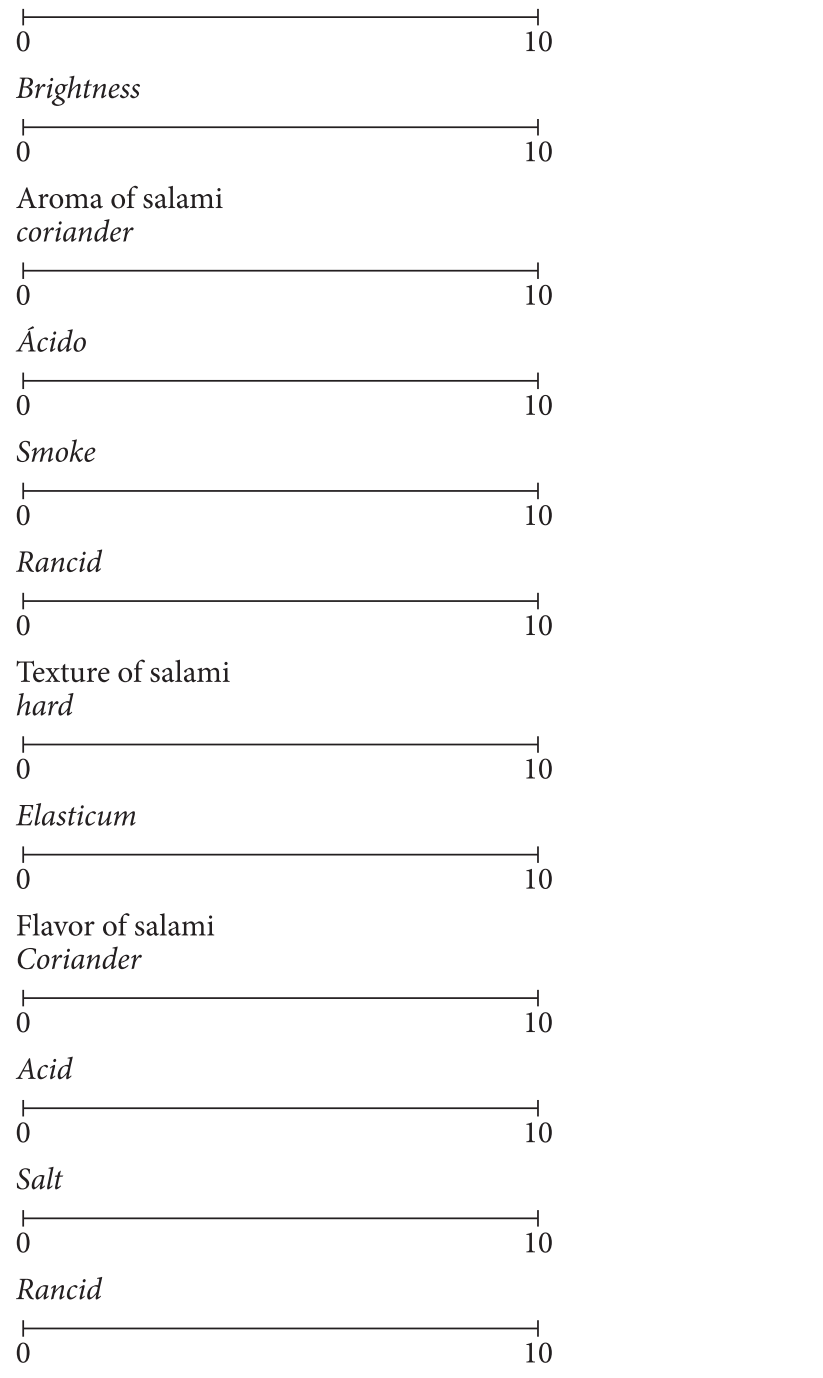

Figure 2. Data used in the evaluation of individual samples for free profile.

\subsection{Principal components analysis}

In Figure 4 is a Principal Components Analysis (PCA) graph, in which it is possible to see the attributes that better characterize the treatments. The Treatment 1 and 3 were characterized by the attributes of taste and flavor rancid. Treatment 2 was characterized by the mandates of coriander flavor and aroma of cilantro. Treatment 4 was characterized by the attributes of brightness and color red.

In the PCA graph, the higher the decomposition of the components,vector on the axle the greater their importance to 


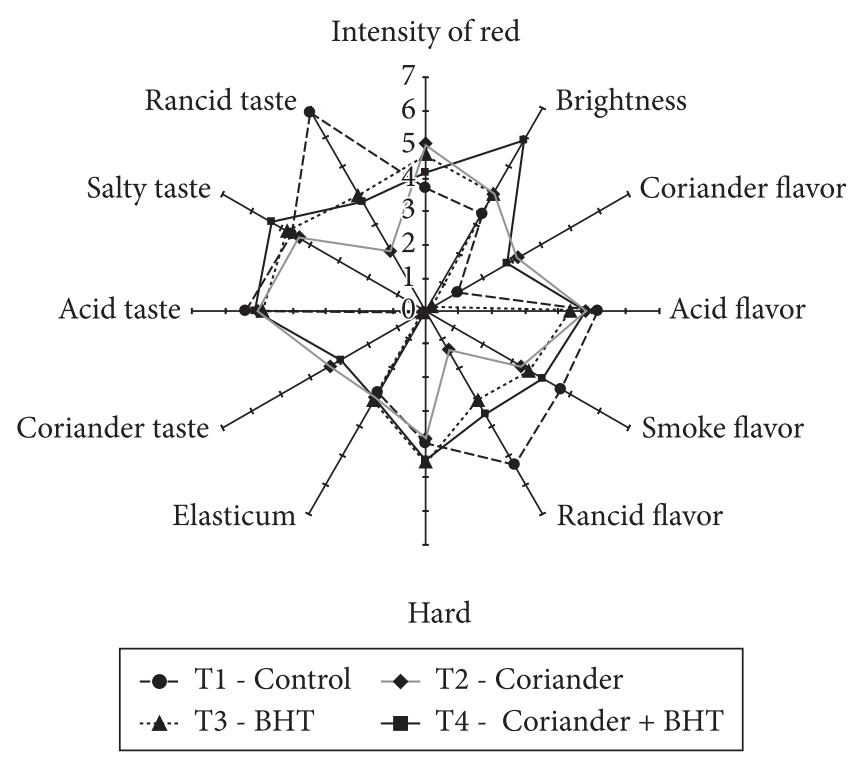

Figure 3. sensory profile of the four treatments of Italian salami with 90 days of storage.

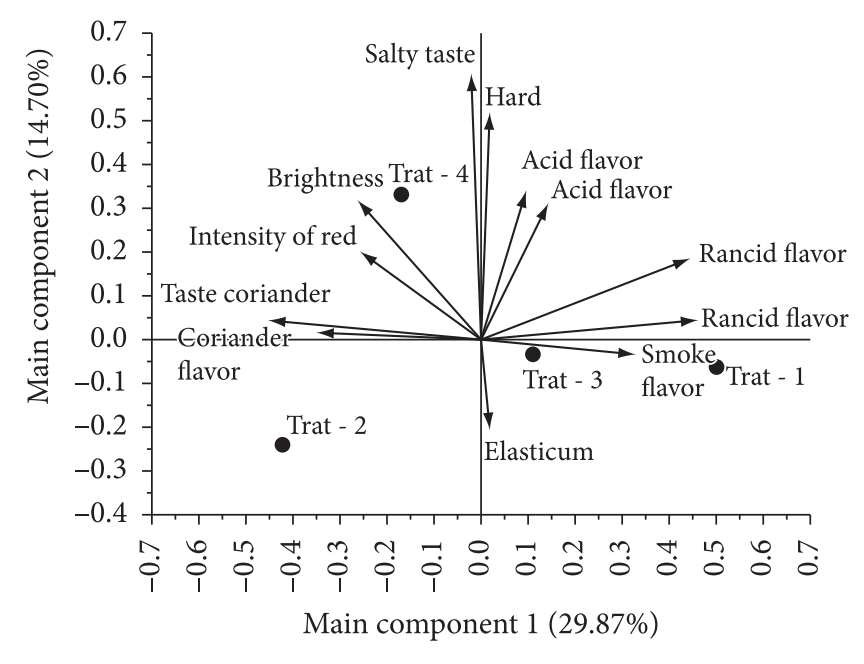

Figure 4. Projection of two-dimensional Principal Component Analysis of the Italian salami samples for the descriptive terms of descriptors.

Table 1. Averages of the scores assigned by the panelists to each descriptive term for the treatments of Italian salami with 90 days of storage.

\begin{tabular}{|c|c|c|c|c|}
\hline \multirow{2}{*}{$\begin{array}{l}\text { Descriptive } \\
\text { terms }\end{array}$} & \multicolumn{4}{|c|}{ Treatments } \\
\hline & $\begin{array}{c}\mathrm{T} 1 \\
\text { (Control) } \\
\end{array}$ & $\begin{array}{c}\mathrm{T} 2 \\
(0.01 \% \text { coriander })\end{array}$ & $\begin{array}{c}\mathrm{T} 3 \\
(0.01 \% \mathrm{BHT}) \\
\end{array}$ & $\begin{array}{c}\mathrm{T} 4 \\
(0.005 \% \text { Coriander }+0.005 \% \mathrm{BHT})\end{array}$ \\
\hline Intensity of red & $\begin{array}{c}3.68^{\mathrm{a}} \\
( \pm 1.67)\end{array}$ & $\begin{array}{c}5.01^{\mathrm{b}} \\
( \pm 0.55)\end{array}$ & $\begin{array}{c}4.71^{\mathrm{ab}} \\
( \pm 122)\end{array}$ & $\begin{array}{c}4.13^{\mathrm{ab}} \\
( \pm 0.72)\end{array}$ \\
\hline Brightness & $\begin{array}{c}3.37^{\mathrm{a}} \\
( \pm 0.90)\end{array}$ & $\begin{array}{c}4.07^{\mathrm{a}} \\
( \pm 0.80)\end{array}$ & $\begin{array}{c}4.06^{\mathrm{a}} \\
( \pm 1.32)\end{array}$ & $\begin{array}{c}5.90^{\mathrm{b}} \\
( \pm 0.98)\end{array}$ \\
\hline Coriander flavor & $\begin{array}{c}1.11^{\mathrm{b}} \\
( \pm 0.26)\end{array}$ & $\begin{array}{c}3.20^{c} \\
( \pm 0.75)\end{array}$ & $\begin{array}{c}0.23^{\mathrm{a}} \\
( \pm 0.28)\end{array}$ & $\begin{array}{c}2.80^{c} \\
( \pm 0.67)\end{array}$ \\
\hline Acid flavor & $\begin{array}{c}5.16^{\mathrm{a}} \\
( \pm 0.86)\end{array}$ & $\begin{array}{c}4.80^{\mathrm{a}} \\
( \pm 0.59)\end{array}$ & $\begin{array}{c}4.31^{\mathrm{a}} \\
( \pm 1.05)\end{array}$ & $\begin{array}{c}4.80^{\mathrm{a}} \\
( \pm 0.76)\end{array}$ \\
\hline Smoke flavor & $\begin{array}{c}4.70^{c} \\
( \pm 0.72)\end{array}$ & $\begin{array}{c}3.30^{\mathrm{a}} \\
( \pm 0.57)\end{array}$ & $\begin{array}{c}3.56^{\mathrm{ab}} \\
( \pm 0.77)\end{array}$ & $\begin{array}{c}4.05^{\mathrm{bc}} \\
( \pm 0.49)\end{array}$ \\
\hline Rancid flavor & $\begin{array}{c}5.35^{\mathrm{c}} \\
( \pm 0.43)\end{array}$ & $\begin{array}{c}1.35^{\mathrm{a}} \\
( \pm 0.47)\end{array}$ & $\begin{array}{c}3.10^{\mathrm{b}} \\
( \pm 1.95)\end{array}$ & $\begin{array}{c}3.55^{\mathrm{b}} \\
( \pm 1.31)\end{array}$ \\
\hline Rigidity & $\begin{array}{c}3.97^{\mathrm{a}} \\
( \pm 0.87)\end{array}$ & $\begin{array}{c}3.8^{\mathrm{a}} \\
( \pm 0.55)\end{array}$ & $\begin{array}{c}4.51^{\mathrm{a}} \\
( \pm 0.84)\end{array}$ & $\begin{array}{c}4.48^{\mathrm{a}} \\
( \pm 0.59)\end{array}$ \\
\hline Elasticity & $\begin{array}{c}2.79^{\mathrm{a}} \\
( \pm 0.45)\end{array}$ & $\begin{array}{c}3.01^{\mathrm{a}} \\
( \pm 0.58)\end{array}$ & $\begin{array}{c}3.10^{\mathrm{a}} \\
( \pm 0.95)\end{array}$ & $\begin{array}{c}3.03^{\mathrm{a}} \\
( \pm 0.79)\end{array}$ \\
\hline Coriander taste & $\begin{array}{c}0.05^{\mathrm{a}} \\
( \pm 0.079)\end{array}$ & $\begin{array}{c}3.33^{c} \\
( \pm 0.35)\end{array}$ & $\begin{array}{c}0.09^{\mathrm{a}} \\
( \pm 0.12)\end{array}$ & $\begin{array}{c}2.88^{\mathrm{b}} \\
( \pm 0.52)\end{array}$ \\
\hline Acid taste & $\begin{array}{c}5.37^{\mathrm{a}} \\
( \pm 0.96)\end{array}$ & $\begin{array}{c}5.03^{\mathrm{a}} \\
( \pm 0.71)\end{array}$ & $\begin{array}{c}4.87^{\mathrm{a}} \\
( \pm 1.03)\end{array}$ & $\begin{array}{c}5.09^{\mathrm{a}} \\
( \pm 0.82)\end{array}$ \\
\hline Salty taste & $\begin{array}{c}4.59^{\mathrm{a}} \\
( \pm 0.49)\end{array}$ & $\begin{array}{c}4.36^{\mathrm{a}} \\
( \pm 0.71)\end{array}$ & $\begin{array}{c}4.78^{\mathrm{ab}} \\
( \pm 0.41)\end{array}$ & $\begin{array}{c}5.30^{\mathrm{b}} \\
( \pm 0.75)\end{array}$ \\
\hline Rancid taste & $\begin{array}{c}6.85^{\mathrm{c}} \\
( \pm 1.00)\end{array}$ & $\begin{array}{c}2.05^{\mathrm{a}} \\
( \pm 0.51)\end{array}$ & $\begin{array}{c}4.01^{\mathrm{b}} \\
( \pm 0.70)\end{array}$ & $\begin{array}{c}3.77^{\mathrm{b}} \\
( \pm 0.74)\end{array}$ \\
\hline
\end{tabular}

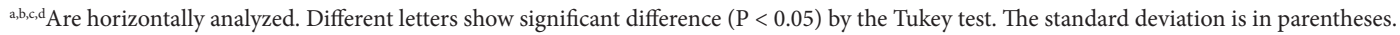

characterize the differences between the samples. In this case, the sum of the main components was $44.57 \%$.

\section{Conclusions}

Based on the results obtained using the essential oil in Italian salami, it can be concluded that: the Italian salami that received the addition of additives, i.e. BHT or coriander essential oil, resulting in salami with lower scores for the sensory of stale taste and smell of confirming the delay on lipid oxidation in the control salami.

The sensory profile attributes for rancid aroma and taste indicate that the use of coriander essential oil presented 
higher synthetic antioxidant effect of BHT (butyl hydroxytoluene) delaying lipid oxidation.

The coriander essential oil improved the sensory attributes of taste, odor, texture, brightness, and intensity of red in Italian salami.

\section{References}

BRASIL. Instrução Normativa n. 22, de 31 de julho de 2000. Regulamento técnico de identidade e qualidade do salame tipo italiano. Diário Oficial [da] República Federativa do Brasil, Brasília, DF, 3 ago. 2000. Seção 1, n. 149, p. 24-25.

DAMÁSIO, M. H.; SILVA, M. A. P. Análise sensorial descritiva: fundação tropical de pesquisas e tecnologia "André Tosello". Campinas, 1996.

GILLETTE, M. Aplications of descriptive analysis. Journal of Food Protection, v. 47, n. 5, p. 403-409, 1984.
GONÇALVES, J. R. O extrato de alecrim como antioxidante em produtos cárneos. 2009. n. 384, p. 68-69.

KROON, P. A.; WILLIAMSON, G. Hydroxycinnamates in plant and food: current and future perspectives. Journal of the Science of Food and Agriculture, v. 79, n. 3, p. 355-361, 1999.

MELO, E. A.; GUERRA, N. B. Ação antioxidante de compostos fenólicos naturalmente presentes em alimentos. Boletim SBCTA, v. 36, n. 1, p. 1-11, 2002.

MOSKOWITZ, H. R. Applied sensory analysis of foods. Boca Ratton: CRC Press, 1988. v. 1, 259 p.

PARK, Y. K.; KOO, M. H.; CARVALHO, P. O. Recentes progressos dos alimentos funcionais. Boletim SBCTA, v. 31, n. 2, p. 200-206, 1997.

STATISTICAL ANALYSIS SYSTEM INSTITUTE - SAS. Versão 8. Cary: SAS, 2001.

STONE, H. et al. Sensory evaluation by quantitative descriptive analysis. Food Technology, v. 28, n. 11, p. 24-34, 1974.

STONE, H.; SIDEL, J. L. Sensory evaluation practices. 2. ed. San Diego: Academic Press, 1992. 308 p. 